\title{
Measuring the environmental sustainability of a major sporting event: a case study of the FA Cup Final
}

\author{
ANDREA COLLINS AND ANDREW FLYNN \\ School of City and Regional Planning, Cardiff University, Glamorgan Building, King \\ Edward VII Avenue, Cardiff CF10 3WA, UK. E-mail: collinsa@cardiff.ac.uk; \\ flynnac@cardiff.ac.uk.
}

\begin{abstract}
Policymakers are increasingly interested in the wider consequences of major sporting events, including their environmental impacts. Indeed, London 2012 included as part of its winning Olympic bid a commitment to measure and take steps to minimize the environmental impacts of the forthcoming Games. This paper demonstrates how the 'Ecological Footprint' has been used to measure the environmental sustainability of the UK's Football Association (FA) Cup Final. This approach provides valuable insights into the global environmental impacts generated by visitor consumption patterns. The paper also demonstrates how this tool can support policymakers and event organizers in staging sustainable events through the development and assessment of policy scenarios.
\end{abstract}

Keywords: ecological footprint; environmental assessment; environmental sustainability; sport tourism; FA Cup Final; London 2012 Olympic Games

In addition to the economic impacts associated with major events, policymakers and event organizers are increasingly interested in their environmental impacts. More specifically in relation to sport events, there has been increased attention, especially at the international level, to take action to reduce their environmental impacts. For example, the organizers of the 1994 Winter Olympic Games in Lillehammer developed a comprehensive environmental action plan, and the 2000 Summer Olympic Games in Sydney took steps towards staging the first 'green games'. More recently, organizers of the 2006 World Cup Football competition in Germany introduced Green GoalTM as the first environmental initiative at a FIFA World Cup and set environmental protection targets. But, so far, few have sought to measure the total environmental impact of staging an event. So, how might organizers of international and national sports events begin to identify and measure the environmental impacts associated with 
staging major sporting events? One approach is to apply the Ecological Footprint (EF). The EF is becoming an increasingly popular tool by which to identify those resources that are being consumed by citizens and assess their global environmental impact. In a highly novel application, we have applied the EF to a major sport event - the FA Cup Final - in Cardiff, the capital city of Wales (UK). If the EF can be applied to this event successfully, then it has the potential to be applied to other major sporting events, including the London 2012 Olympic Games and World Cup Competitions.

\section{Structure of the paper}

This paper is structured as follows. First, the football industry's current response to the environmental impacts associated with the sport is described. The next section then explains what an EF is and why it may be a valuable tool from which to assess the environmental impacts of major sporting events. Here, we also explain briefly how an EF is calculated. Following this, we explain how the EF of the case event - the 2004 FA Cup Final - was measured. The subsequent section presents and discusses the EF results of the case event. Based on these results, we identify those areas of visitor consumption that are a priority in terms of their resource use and we demonstrate how the EF can be used to assess the extent to which different scenarios could reduce the environmental impacts of the event. The final section provides a discussion on the value of using the EF approach to measure the environmental sustainability of an event, and also those difficulties that were encountered.

\section{Football industry and the environment: current state of play}

In the football industry, it is primarily at an international level that environmental and sustainability issues are starting to be recognized and addressed. FIFA (the Fédération Internationale de Football Association), the international governing body of the sport, has engaged with environmental issues for almost ten years. The approach adopted has focused on promoting and raising awareness of local environmental issues through football development projects such as 'slum clean-up sessions' in developing countries. However, it has only been more recently that there has been recognition of the wider environmental impacts associated with staging major football events. It was at the 2006 FIFA World Cup that organizers in Germany voluntarily pursued the goal to reduce some of the environmental impacts of the tournament through its Green GoalTM environmental initiative, which set environmental protection targets.

At a European level, UEFA (the Union of European Football Associations), the governing body of football in Europe, has also responded to increased pressure to organize green games. Following the signing of a Sustainable Development Charter in June 2007, UEFA plans to use the 2008 European tournament in Austria as an opportunity to provide a benchmark and set a standard for future championships. Key issues being addressed include the 
development of more environmentally friendly stadiums and improved public transport to encourage supporters to leave their cars at home.

But what interest has there been at the national level? In the UK, the Premiership League and Football Association (FA) currently does not force or encourage clubs to consider the environmental impacts of their operations and take action to minimize those impacts. In an attempt to gain an insight as to what steps are being taking by local football clubs on a voluntary basis, a review was undertaken of those clubs that were part of the Premiership League in 2007. This involved reviewing reports and other literature made publicly available on individual club websites. Of the 20 clubs reviewed, it was found that few had policies in place or were voluntarily engaging in projects to minimize their environmental impacts. Manchester City Football Club (MCFC) was found to be the only club that was actively engaged in projects to reduce the negative environmental impacts of the club's activities and its supporters attending matches at the stadium. In recent years, MCFC, through its Environmental Awareness Programme, has developed a number of environmental initiatives designed to raise awareness of environmental issues and encourage sustainable behaviours amongst its partners and supporters. These include recycling of waste, reduced packaging, procurement of local food and a transport strategy which encourages supporters' use of public transport and the provision of a safe walking route linking the city centre to the City of Manchester Stadium. More recently, MCFC announced that it would be erecting an $85 \mathrm{~m}$ wind turbine adjacent to the stadium, which would supply enough energy to power the stadium and any excess would be made available to local residents.

Although it is primarily at an international and European level that the environmental impacts associated with the football industry are starting to be addressed, so far few have sought to measure the total environmental impact of staging a major event. The reason for this could be that the environmental impacts are perceived as being small, as events are limited primarily to one day and therefore clubs and national administrations choose to ignore them. So, how might organizers begin to identify and measure the environmental impacts associated with staging major sporting events? One approach is to apply the EF. In the following section, we explain what an EF is and why it may be a valuable tool from which to assess the environmental impacts of major sporting events. We then describe how an EF was calculated for the 2004 FA Cup Final.

\section{Ecological Footprint analysis}

Although we have chosen to analyse the environmental impacts arising from an FA Cup Final through the EF methodology, there are a number of ways in which the event could have been studied. For example, environmental and ecological economists have sought to analyse resource use (see, for example, the review by Pezzey and Toman, 2002). Environmental economists are much more sympathetic to neoclassical welfare theory and microeconomics than ecological economists (van den Bergh, 2001). Conventional environmental economists point out that the degradation of the environment arises because natural 
resources are unpriced and so operate outside of the market. For environmental economists, the task is to secure the efficiency of resource use. Since environmental problems are conceived as an externality, the object is to reduce such non-market effects by assigning monetary values to environmental losses (and services). Ecological economists, meanwhile, adopt a less orthodox conceptual and methodological approach in which they seek explicitly to engage with 'people-environment or economic-ecological relations' (van den Bergh, 2001, p 15). As a result, ecological economists have discussed more fully the meaning of sustainable development and contributed to debates on environmental limits. Ecological economists are also much more sympathetic to methodologies and indices that explore the relationship between the economy and the environment (Martinez-Alier, 1990).

Ecological economists have adopted divergent attitudes towards the EF. For example, Martinez-Alier (1990) is sympathetic to the question raised by the Footprint (and similar notions such as Ecological Space): 'how large an area of productive land is needed (as an environmental source and sink) in order to sustain a population at their current standard of living?' However, van den Bergh (2001, pp 18-19) argues that the Footprint is too crude a measure to distinguish different types of environmental pressure or of their relative weight. Environmental economists would also point out that the Footprint does not take into account that land has different values or pay sufficient attention to externalities. In our discussion of the EF below, we return to these points.

Ecological Footprint analysis was pioneered in the early 1990s (see Wackernagel and Rees, 1996). The starting point for the EF concept is that there is a limited amount of bioproductive land on the earth to provide for all human resource demands. Sustainable development requires that we live within the carrying capacity of the earth, allowing our economies to develop whilst still ensuring that human needs are met. The EF is an aggregated indicator of global environmental impact and is measured using a standardized area unit equivalent to a world average productive hectare or 'global hectare' (gha), which is usually expressed in global hectares per capita (gha/cap).

Whereas economists are interested in the different (economic) values attached to land, EF modellers are concerned with attributing an environmental value to land. For example, economists would wish to attribute a higher value to a unique habitat than to agricultural land, but Footprint modellers use quite different categories. This is because the EF is derived for a defined population by estimating the area of bioproductive land and sea required to support their resource consumption using prevailing technology; for example, demands in terms of energy use, food and drink consumption, travel and waste. This demand on nature can be compared with the available Earth's biocapacity, which translated into an average $1.8 \mathrm{gha} / \mathrm{cap}$ in 2001 (WWF, 2006). However, humanity currently is using 2.2 gha/cap, which indicates a situation of 'overshoot' where nature's capital is being spent faster than it is being regenerated (WWF, 2006). Overshoot may reduce the earth's ecological capacity permanently and this is a key concern for sustainability. The EF concept has gained widespread appeal and provides an innovative approach to communicating messages about the global impact of current resource consumption. 
Although the EF is being used widely and applied in the UK and elsewhere, the concept has faced a number of criticisms. Amongst the main points, critics have argued that the Footprint does not reflect the impacts of human consumption accurately (see van den Bergh and Verbruggen, 1999; Lenzen and Murray, 2001; Ferng, 2002); it does not allocate responsibilities of impact correctly (see McGregor et al, 2004); and does not provide decision makers with a useful tool for policymaking, as there is limited understanding of how different consumer activities relate to impact (see van den Bergh and Verbruggen, 1999; Ayres, 2000; Moffatt, 2000; Ferng, 2002). A more recent critique of the EF can be found in McDonald and Patterson (2004, pp 52-54) and a more general debate can be found in van Vuuren and Smeets (2001).

A specific concern for environmental economists is that whilst the EF may capture explicitly the price that users pay for some goods and services, it will not be comprehensive and the latter can be regarded as externalities. However, from the viewpoint of EF analysts, whether or not an environmental resource has a market value is not the point. Rather, those who work within an EF framework are keen to identify the resources required to meet our consumption demands and assimilate our wastes. In policy terms, it means that the greatest contribution to ecological sustainability may well come, not from environmental protection or a supply-side emphasis on improved resource management but rather from efforts to reduce demand' (Rees, 2003, p 42). So, whilst from an environmental economics perspective a reduction in the EF ideally should lead to a reduction in environmental services that are not priced, the externalities from an EF perspective are not considered.

Despite criticisms of the EF method, it is becoming an ever more popular tool. It does offer a number of advantages to those wanting to understand and measure the impact of major events, and also to those who plan and organize large-scale events. One potentially large contribution is that as the EF relates to the consumption activities of a defined population, it potentially has many applications. For example, in the UK, the Footprint has had a number of uses, including products, organizations, services, different levels of government, proposed large-scale developments and tourism (see Barrett and Scott, 2003; Barrett et al, 2005; Collins and Flynn, 2005; Collins et al, 2005, 2006). Here, we apply the concept to the visitor consumption that occurs at a major sporting event, the FA Cup Final. This approach is useful here, for a number of reasons. First, the Footprint method provides valuable insights into natural resource use and an estimate of the land area required to support that level of consumption. As the EF aggregates the impacts of different consumption activities into a single measure, it also offers policymakers the potential to identify clearly and compare the environmental impact of different visitor activities such as transport, waste and energy use. Second, the Footprint provides the potential for policymakers and event organizers to prioritize their actions in a more informed and integrated manner. Third, the Footprint may be good as an awareness-raising tool as it personalizes sustainability by assessing the impact of consumption from a consumer perspective (that is, it takes into account the impact of residents within a defined boundary, rather than the industries in a particular locality). So, by converting the resource use of visitors to an area of land, the global hectare, the EF presents itself as a powerful communication tool. The Footprint can therefore be a useful tool by which to communicate with people and for them to appreciate 
the link between their local consumption activities and global environmental impacts. A significant advantage of the EF over a number of other environmental appraisal tools is that it provides decision makers with information on ecological impacts rather than asking them to make judgements. Used sensitively, the EF can provide a benchmark against which developments and events can be calculated. Moreover, since the Footprint measures the impact of consumption activities, these can be linked to the responsibilities of different organizations and so provide an agenda for change (that is, a Footprint reduction). Finally, the EF can be used to analyse the impact of different policy options; for example, increased visitor journeys by public transport. This can inform policymakers and assist event organizers in planning and minimizing the environmental impacts of major events.

\section{Calculating Ecological Footprints}

Traditionally, national EFs (the 'National Footprint Accounts') have been calculated based on a country's domestic production, imports and exports of primary and secondary products, together with an estimate of the embodied energy of secondary products (Monfreda et al, 2004). However, this method does not assign resource flows to final consumption categories accurately as it omits all mutual interrelationships between product sectors and excludes the environmental effects of tertiary products, services, for example. Recent methodological developments by the Stockholm Environment Institute (SEI) have allowed intermediate resource flows to be assigned to final consumption, thereby adding significant strength to the EF calculation (see Barrett et al, 2005; Wiedmann et al, 2006). The Footprinting method then (following Barrett et al, 2005) takes the existing National Footprint Account provided by the Global Footprint Network (GFN, 2004) as a starting point. The total Footprint of the UK is then disaggregated by economic sector and re-allocated to final demand by using input-output analysis based on economic supply and use tables. The breakdown of final demand categories includes detailed household consumption activities according to the international 'Classification of Individual Consumption According to Purpose' (COICOP) classification system and a detailed breakdown of capital investment. For a comprehensive description of this method, see Wiedmann et al (2006). With this method, it is possible to calculate Footprints for subnational areas or socio-economic groups, and the approach has been used successfully to calculate the Footprint of the UK, Wales and Cardiff (see Barrett et al, 2005; Collins et al, 2005, 2006). Here, we have used the methodology developed by SEI as the basis for our Footprint calculations of the 2004 FA Cup Final.

\section{Cardiff and UK Ecological Footprint results (2001)}

An EF study of Cardiff has calculated that in 2001 the Footprint of an average Cardiff resident was 5.59 gha/capita (see Collins et al, 2005), which is greater than the Footprint of an average UK resident ( 5.35 gha/cap) (see Table 1). These figures show that the level of consumption by Cardiff residents is currently inequitable as they are using resources more than three times the average 'earthshare' of 1.8 gha/cap. In terms of equity, Cardiff's residents would need to reduce their ecological demand by $68 \%$ to reach the average 'earthshare'. 
Table 1. Comparison of the Ecological Footprints of UK and Cardiff (2001).

Component areas

Household consumption

Food and drink

Energy

Travel

Housing

Consumables

Services

Holidays abroad

Non-household consumption

Capital investment

Government

Other

Credits for recycling

Total

Waste (satellite account)
Cardiff

(gha/capita)
UK

(gha/capita)

$\begin{array}{cc}1.33 & 1.34 \\ 0.99 & 0.90 \\ 0.99 & 0.72 \\ 0.16 & 0.18 \\ 0.64 & 0.75 \\ 0.26 & 0.32 \\ 0.10 & 0.12 \\ & \\ 0.74 & 0.74 \\ 0.41 & 0.41 \\ -0.03 & 0.12 \\ -0.030 & -0.108 \\ 5.59 & 5.35 \\ 0.81 & 0.71\end{array}$

Table 1 shows the EF results for Cardiff and the UK in 2001 and the relative size of the different components in the Footprint. The results for Cardiff show that food and drink is the single largest component and accounts for almost $24 \%$ of the total Footprint figure, and together with three other components - travel, energy and consumables - contributes $70 \%$ of the total Footprint. That four factors dominate the Cardiff Footprint is indicative of how contemporary patterns of consumption have major implications for resource use. As the Footprint methodology used here considers the environmental impacts of consumables, to avoid double counting, the Footprint of waste is treated as a satellite account. Cardiff's household waste has a Footprint result of 0.81 gha/ capita (see Collins et al, 2005). 'Credits for recycling' in Cardiff produces a negative Footprint of -0.030 gha/capita as recycled materials re-enter the economy (see Table 1).

Cardiff's EF results can also be broken down into six different land types; energy, crop, pasture, built land, sea and forest (see Table 2). This is known as the compound approach to ecological footprinting (see Wackernagel and Rees, 1996). The type of land area which contributes the most to the Cardiff Footprint is 'energy land', the land area required to sequester carbon dioxide emissions from fossil fuel energy consumption. This is then followed by crop and sea land. When combined, these land types account for almost $80 \%$ $(79.4 \%)$ of the Cardiff EF.

\section{Measuring the Ecological Footprint of the 2004 FA Cup Final}

There are several reasons for selecting and applying the EF approach to this particular event. First, the Cardiff EF study involved calculating the Footprint 
Table 2. Cardiff Ecological Footprint land type summary (2001).

\begin{tabular}{lccccccr}
\hline $\begin{array}{l}\text { Component } \\
\text { areas }\end{array}$ & $\begin{array}{c}\text { Total } \\
\text { Cardiff EF } \\
\text { (gha/cap) }\end{array}$ & $\begin{array}{c}\text { Energy } \\
\text { EF } \\
\text { (gha/cap) }\end{array}$ & $\begin{array}{c}\text { Crop } \\
\text { EF } \\
\text { (gha/cap) }\end{array}$ & $\begin{array}{c}\text { Pasture } \\
\text { EF } \\
\text { (gha/cap) }\end{array}$ & $\begin{array}{c}\text { Built } \\
\text { land EF } \\
\text { (gha/cap) }\end{array}$ & $\begin{array}{c}\text { Sea } \\
\text { EF } \\
\text { (gha/cap) }\end{array}$ & $\begin{array}{c}\text { Forest } \\
\text { EF }\end{array}$ \\
Food and drink & 1.33 & 0.281 & 0.438 & 0.215 & 0.011 & 0.356 & 0.030 \\
Energy & 0.99 & 0.894 & 0.001 & 0.000 & 0.085 & 0.001 & 0.005 \\
Travel & 0.99 & 0.577 & 0.009 & 0.004 & 0.039 & 0.008 & 0.014 \\
Capital investment & 0.74 & 0.560 & 0.034 & 0.016 & 0.013 & 0.009 & 0.112 \\
Consumables & 0.64 & 0.387 & 0.122 & 0.058 & 0.018 & 0.033 & 0.054 \\
Government & 0.41 & 0.312 & 0.018 & 0.009 & 0.021 & 0.016 & 0.032 \\
Services & 0.26 & 0.164 & 0.020 & 0.010 & 0.013 & 0.030 & 0.019 \\
Housing & 0.16 & 0.087 & 0.016 & 0.008 & 0.004 & 0.008 & 0.035 \\
Holiday activities & 0.10 & 0.037 & 0.022 & 0.011 & 0.002 & 0.028 & 0.004 \\
Other & -0.03 & 0.024 & -0.016 & -0.008 & 0.008 & -0.038 & -0.001 \\
Total & 5.59 & 3.323 & 0.665 & 0.322 & 0.212 & 0.453 & 0.304 \\
\hline
\end{tabular}

of Cardiff's near 11 million annual tourists. Results showed that a Cardiff tourist had a significant ecological impact and had a larger Footprint than a Cardiff resident (8.67 gha/tourist compared to 5.59 gha/capita) (see Collins et al, 2005, 2006). Second, tourism is an important part of Cardiff's development strategy as an 'events city' (Jones, 2001). Cardiff has hosted the FA Cup Final since 2001 and it is one of the city's most high-profile annual sporting events. The potential environmental implications of hosting this particular sports event were such that they could not be ignored. Measuring the EF of a major sporting event such as the FA Cup Final would represent a novel application of the tool. The findings from this research would provide, for the first time, detailed information on visitor consumption patterns at a major sporting event and provide a measurement of their global ecological impacts.

Similar to the waste component of the EF, tourists also take the form of a satellite account. The Footprint of tourists can be calculated using two different methods; top-down and bottom-up. The 'top-down' approach calculates the Footprint using modelled expenditure data, and the 'bottom-up' approach uses locally specific data. Whilst the top-down approach can be useful in providing an indication of visitor impact, the consumption patterns of visitors at an event such as the FA Cup Final will be event specific. For the purposes of this case event, it was necessary to use the bottom-up approach as the collection and use of primary data relating specifically to the event would provide a more accurate account of visitor consumption and its environmental consequences.

\section{Background to the case event: the 2004 FA Cup Final}

The FA Cup Final is one of the most prestigious competitions for football clubs in the UK and is arguably one of the greatest single matches in world club football. Cardiff, the capital city of Wales, has hosted the FA Cup Final event 
(and other major football matches, including the Worthington Cup Final) at the Millennium Stadium since 2001, whilst the Wembley Stadium in London was being rebuilt. In 2004, the two football teams to reach the Cup Final were Manchester United Football Club and Millwall Football Club. An estimated 73,000 football supporters travelled to Cardiff for the event, of which 71,350 were spectators in the Millennium Stadium. Based on ticket sales information provided by The FA, it was estimated that $70 \%$ of spectators were supporters of Manchester United Football Club and 30\% were supporters of Millwall Football Club.

\section{Estimating visitor consumption}

Events can attract a range of visitors, but not all should be included when calculating the EF as not all visitors will be in the host city specifically for the event. As highlighted by Clarke (2004), within any tourist destination there will be a population of general tourists who will visit for a number of reasons. This may or may not include attending the event in question. This subsequently raises questions related to attribution - what proportion of general tourists in a destination should be attributed to the event in question? For the case event, the geographical boundary of the study was taken to be the host city of Cardiff. The study population was all event visitors and included both ticket and nonticket holders. Based on information provided by Cardiff County Council, the majority of visitors travelled to Cardiff on match day, and therefore the period for which visitors' EF was calculated was one day (that is, the day of the Cup Final). Primary data relating to visitor consumption were collected for visitor travel, food and drink consumption, infrastructure of the event venue and waste, as they were considered to have the most significant impacts. Below, we outline briefly how visitor consumption is calculated for each of these.

The transport component of the EF was calculated based on visitors' mode of travel and return distances travelled from their home location to the event venue. The amount of food and drink consumed by visitors attending the event was calculated using business sales data on items sold on the match day and an estimation of the proportion of customers that were event visitors. Sales data were obtained from food and drink businesses in Cardiff city centre and bay area, licensed mobile food operators and caterers operating at the event venue.

The EF of the event venue (that is, the Millennium Stadium) was calculated based on the quantity and composition of materials used to build the venue and supply all fittings and services, together with an estimation of the expected lifespan of the venue and number of visitors attending events during that period. The waste EF was calculated based on the quantity and composition of waste generated on the day of the event and how it was subsequently managed and disposed of (that is, recycled or sent for landfill). This included waste collected from the event venue, food and drink businesses, licensed mobile food operators, coach and car parks, street sweepings and litters bins from streets adjacent to the event venue. For a more detailed description of the methodology, including data collection methods, data sources and assumptions made in calculations, see Collins et al (2007). In the following section, we present and discuss the EF results for the 2004 FA Cup Final. 
Table 3. Ecological Footprint of 2004 FA Cup Final.

\begin{tabular}{|c|c|c|c|}
\hline Category & $\begin{array}{l}\text { Visitor total } \\
\text { Ecological } \\
\text { Footprint } \\
\text { (gha/day) }\end{array}$ & $\begin{array}{l}\text { Visitor Ecological } \\
\text { Footprint at home } \\
\text { location per day } \\
\text { (gha/day) }\end{array}$ & $\begin{array}{l}\text { Visitor additional } \\
\text { Ecological } \\
\text { Footprint } \\
\text { (gha/day) }\end{array}$ \\
\hline Food and drink & $\begin{array}{l}1,413 \\
\text { (0.0194 gha/visitor) }\end{array}$ & $\begin{array}{l}266 \\
(0.0036 \mathrm{gha} / \text { visitor })\end{array}$ & $\begin{array}{l}1,147 \\
(0.0157 \mathrm{gha} / \text { visitor })\end{array}$ \\
\hline Drinks (alcoholic) & 502 & 26 & 477 \\
\hline Drinks (non-alcoholic) & 81 & 9 & 72 \\
\hline Meat and meat products & 654 & 88 & 566 \\
\hline Cereals & 35 & 19 & 16 \\
\hline Fruit and vegetables & 20 & 27 & -7 \\
\hline Oils, fats and spreads & 60 & 10 & 50 \\
\hline Milk and dairy products & 55 & 75 & -20 \\
\hline Sugar and confectionary & 6 & 11 & -4 \\
\hline Other & Negligible & 2 & -2 \\
\hline Transport (ex. air $)^{b}$ & $\begin{array}{l}1,670 \\
(0.0229 \mathrm{gha} / \text { visitor })\end{array}$ & $\begin{array}{l}111 \\
(0.0015 \mathrm{gha} / \text { visitor })\end{array}$ & $\begin{array}{l}1,559 \\
(0.0214 \mathrm{gha} / \text { visitor })\end{array}$ \\
\hline Car & 1,139 & 101 & 1,038 \\
\hline Rail & 325 & 2 & 3,234 \\
\hline Coach & 164 & 0.4 & 164 \\
\hline Private hire bus & 41 & 0.5 & 41 \\
\hline Local bus (park and ride) & 0.05 & 3 & -3 \\
\hline $\begin{array}{l}\text { Other modes (inc. } \\
\text { walking, taxi, motorbike) }\end{array}$ & Negligible & 4.3 & -4 \\
\hline Infrastructure ${ }^{c}$ & & & \\
\hline Stadium & 0.10 & - & - \\
\hline Total & $\begin{array}{l}3,083 \\
(0.0422 \text { ghalvisitor })\end{array}$ & $\begin{array}{l}377 \\
(0.0052 \text { ghalvisitor })\end{array}$ & $\begin{array}{l}2,706 \\
(0.0371 \text { ghalvisitor })\end{array}$ \\
\hline Waste $^{\mathrm{d}}$ & $\begin{array}{l}151 \\
(0.0021 \text { gha/visitor })\end{array}$ & - & - \\
\hline
\end{tabular}

Note: ${ }^{a}$ Based on levels of consumption for an average UK resident per day.

${ }^{\mathrm{b}}$ All transport calculations have excluded air travel to enable comparisons to be made.

'The Ecological Footprint of infrastructure for an average UK resident is not directly comparable as it includes the impact of housing and other general infrastructure including offices, schools, etc.

${ }^{\mathrm{d}}$ The Ecological Footprint for event waste is not directly comparable with that of an average UK resident as it includes other household waste such as furniture and garden waste.

\section{FA Cup Final: Ecological Footprint results}

The EF results for the 2004 FA Cup Final are shown in Table 3. Based on those consumption categories included in this study, the total EF of the event was 3,083 gha (0.0422 gha/visitor) (see Table 3). In this case study, the EF was also used to calculate the additional ecological impact generated by the event. This was calculated by estimating visitor resource consumption at their home location (per day) and subtracting this from their total consumption at the event for each of the Footprint component areas. The additional Footprint generated 
by visitors attending the event was 2,706 gha (0.0371 gha/visitor). The additional EF was calculated for the transport and food and drink components only, as comparable data were not available for capital investments (that is, stadium infrastructure) and waste at the visitors' home locations. If the total EF of an average visitor at the event is compared with that estimated at their home location for the same duration (that is, one day), the total impact of the event is found to be eight times greater. This significant difference is not surprising, as visitors attending the FA Cup Final will consume resources in different ways from their normal practices. Below, we analyse the results further and identify those factors that contribute significantly to the event's EF.

Visitor travel to the event had the most significant impact and created an EF of 1,670 gha (0.0229 gha/capita). This Footprint result accounted for $54 \%$ of the total EF of the FA Cup Final. When compared to the travel Footprint of an average visitor at their home location for the same period of time (that is, one day), the visitor's travel Footprint was found to be seven times greater. The most popular mode of visitor travel was by car, which accounted for $47 \%$ of the total distance travelled by all visitors (43,000,000 passenger kilometres). Visitor travel by car had the most significant impact and was responsible for $68 \%$ of the total transport Footprint figure (see Table 3). Although visitor travel by rail accounted for $34 \%$ of the total distance travelled by all visitors, it was responsible for only $20 \%$ of the total travel Footprint figure. The reason for this is that journeys made by rail have an impact of $60 \%$ less than journeys made by car. Travel by all other modes of transport (coach, minibus and park and ride) accounted for $12 \%$ of the total transport Footprint.

The second largest component was visitor food and drink consumption, which created an EF of 1,413 gha (see Table 3). This Footprint figure for visitors was five times greater than that for visitors at their home location over the same time period (that is, one day). The reason for the size of this Footprint result relates primarily to the scale, type and pattern of visitor food and drink consumption at the event. Those individual food and drink items that were consumed in large amounts, namely alcoholic and non-alcoholic drinks $(86.1 \%)$ and meat and meat products $(4.4 \%)$, were highly processed and required substantial amounts of resources and energy to produce. Consequently, these products were found to be responsible for $41.3 \%$ and $46.3 \%$ of the total food and drink Footprint figure, respectively.

As visitors use a range of fixed assets (that is, capital investment) whilst attending the event, for example, shops, car parks, roads and the event venue, it is important that visitor use of these assets is accounted for within the total $\mathrm{EF}$ for the event. Due to difficulties in assessing visitor use of such assets at the event, their total impact could not be accounted for. However, this study did include in its analysis the impact of the event venue, as it was the main fixed asset that the majority of visitors would use during the event. This would also enable comparisons to be made with other areas of visitor consumption, such as visitor travel.

The event venue, Cardiff's Millennium Stadium, is $40,000 \mathrm{~m}^{2}$ and was constructed using some 40,000 tonnes of concrete and 20,000 tonnes of steel. Based on the stadium having an estimated 100-year lifespan and an estimated 100 million visitors attending major events during that period, the venue 
attracts a very low Footprint score of 0.104 gha/event (see Table 3). The reason for this is that the impact of energy and resources used to construct the stadium is apportioned to the total number of visitors that will use the venue during its estimated lifespan.

As previously discussed, the EF for waste is treated as a satellite account so as to avoid double counting. The FA Cup Final generated a total of 59.2 tonnes of waste, of which $62.3 \%$ was glass, $18.3 \%$ food waste and $13.9 \%$ paper and card packaging. The majority of this waste was then sent for landfill, with minimal recycling or composting taking place. This waste and how it was disposed of resulted in a total waste Footprint of 151 gha, or 0.0021 gha/visitor (see Table 5). Food waste and paper and card packaging accounted for $80.4 \%$ and $13.9 \%$ of this Footprint figure, respectively. It is likely that the Footprint result for waste is an underestimate as it includes only waste produced on the day of the event and therefore excludes packaging such as that used to distribute food and drink items to retailers prior to the event.

The EF results show how, within a short space of time, a large ecological impact can be produced by visitors attending major events such as the FA Cup Final. The number of visitors, how they travel to an event, the types of food and drink they consume and the wastes they produce can generate significant ecological impacts. So, how might we begin to reduce the environmental impacts associated with this major event? To begin to provide some possible answers and direction, a number of scenarios have been developed to illustrate how this might be achieved.

\section{Reducing the Footprint of the FA Cup Final}

Understanding visitor consumption and its environmental impact potentially can assist decision makers and those managing events to plan and organize them in such a way as to limit their impact. The input-output approach underpinning the EF methodology used here means that changes in eventrelated consumption patterns can be explored. This has the potential to assist event organizers in assessing the impact of different policy scenarios. In this section, we develop scenarios for three of the component areas: visitor travel, food and drink and waste, and show the extent to which they could impact on the overall EF of the case event.

\section{Reducing the impact of visitor travel}

The most significant area of consumption was visitor travel, which created a total Footprint of 1,670 gha. The car was the most popular mode of travel and was responsible for more than two-thirds (68\%) of this transport Footprint figure. Here, we consider three different travel scenarios and their impact on the transport Footprint figure and total EF for the event.

The first scenario is concerned with the impact of increased car journeys. If the number of visitor journeys made by car increased and replaced those made by rail and coach, this would increase the transport Footprint significantly. For example, a $100 \%$ increase in journeys made by car would create a travel 
Table 4. Impact of scenarios on the transport and the total Footprints.

\begin{tabular}{|c|c|c|c|c|}
\hline Transport scenarios & $\begin{array}{c}\text { Transport } \\
\text { Ecological Footprint } \\
\text { (gha/day) }\end{array}$ & $\begin{array}{c}\% \\
\text { Increase/ } \\
\text { decrease }\end{array}$ & $\begin{array}{c}\text { Total } \\
\begin{array}{c}\text { Ecological Footprint } \\
\text { (gha/day) }\end{array}\end{array}$ & $\begin{array}{c}\% \\
\text { Increase/ } \\
\text { decrease }\end{array}$ \\
\hline $\begin{array}{l}\text { 1. Increased car travel } \\
\text { (replace coach and rail } \\
\text { with car) }(100 \%) .^{\text {a }}\end{array}$ & $\begin{array}{c}2,421.0 \\
(0.0332 \mathrm{gha} / \text { visitor })\end{array}$ & +45.0 & $\begin{array}{c}3,833.8 \\
\text { (0.0525 gha/visitor) }\end{array}$ & +24.4 \\
\hline $\begin{array}{l}\text { 2. Replace car with } \\
\text { coach }(100 \%) .^{\text {b }}\end{array}$ & $\begin{array}{c}974.9 \\
\text { (0.0134 gha/visitor) }\end{array}$ & -41.6 & $\begin{array}{c}2,387.6 \\
(0.0327 \mathrm{gha} / \text { visitor })\end{array}$ & -22.5 \\
\hline $\begin{array}{l}\text { 3. Replace car with } \\
\text { rail }(100 \%))^{\text {b }}\end{array}$ & $\begin{array}{c}983.4 \\
(0.0135 \text { gha/visitor })\end{array}$ & -41.1 & $\begin{array}{c}2,396 \\
(0.0328 \mathrm{gha} / \text { visitor })\end{array}$ & -22.3 \\
\hline
\end{tabular}

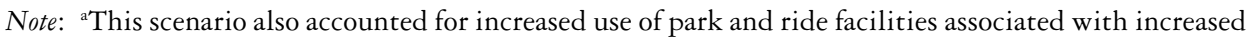
car travel.

${ }^{\mathrm{b}}$ These scenarios also accounted for decreased use of park and ride facilities associated with decreased car travel.

Footprint of 2,421 gha, an increase of almost $45 \%$ (see Table 4). Overall, this scenario would increase the total EF of the event by almost $25 \%$.

The second and third transport scenarios consider the impact of increased visitor travel by rail and coach, both of which have a lower ecological impact than the car. As shown in Table 4, if coach or rail replaced all car travel, both of these scenarios could each reduce the transport Footprint by almost $42 \%$. The overall impact of this shift in travel from car to coach or rail could reduce the transport Footprint by more than $41 \%$ and the total EF of the event by almost $23 \%$. Overall, these travel scenarios suggest that to reduce the impact of visitor travel, event organizers should focus on encouraging visitors to travel to the event by public transport (that is, rail or coach), rather than, for example, promoting the use of event 'park and ride' facilities, as the largest proportion of visitor journeys will have been made by car.

\section{Reducing the impact of visitor food and drink consumption}

Food and drink was another area of visitor consumption that generated a large ecological impact (1,413 gha for all visitors). The food scenarios developed here consider changing the types of food and drink that visitors consume, whether food items are produced locally or imported and whether they are produced conventionally or organically.

Visitor consumption of meat and meat products at the event was responsible for $46 \%$ of the total food Footprint figure. Beef alone accounted for $81.4 \%$ of the total impact of all meat and meat products. The first food scenario considers replacing all beef products with chicken, which has a lower ecological impact per $\mathrm{kg}$, as less energy is needed for its production and processing. As shown in Table 5, if all beef products were replaced with chicken, this could reduce the food Footprint figure by as much as $30.3 \%$ and the total Footprint of the event by $13.9 \%$.

Food and drink that is produced locally in the UK has a lower ecological impact compared to that which is imported, as additional energy is needed for 
Table 5. Impact of scenarios on the food and the total Footprints.

\begin{tabular}{|c|c|c|c|c|}
\hline Food scenarios & $\begin{array}{c}\text { Food } \\
\begin{array}{c}\text { Ecological Footprint } \\
\text { (gha/day) }\end{array}\end{array}$ & $\begin{array}{c}\% \\
\text { Increase/ } \\
\text { decrease }\end{array}$ & $\begin{array}{c}\text { Total } \\
\begin{array}{c}\text { Ecological Footprint } \\
\text { (gha/day) }\end{array}\end{array}$ & $\begin{array}{c}\% \\
\text { Increase/ } \\
\text { decrease }\end{array}$ \\
\hline $\begin{array}{l}\text { 1. Replace all beef } \\
\text { products with chicken } \\
(100 \%) \text {. }\end{array}$ & $\begin{array}{c}984.6 \\
(0.0135 \text { gha/visitor })\end{array}$ & -30.3 & $\begin{array}{c}2,654.6 \\
(0.0364 \mathrm{gha} / \mathrm{visitor})\end{array}$ & -13.9 \\
\hline $\begin{array}{l}\text { 2. Increase consumption } \\
\text { of locally produced } \\
\text { food and drink } \\
(100 \%) \text {. }\end{array}$ & $\begin{array}{c}1,406.4 \\
(0.0193 \text { gha/visitor })\end{array}$ & -0.4 & $\begin{array}{c}3,076.4 \\
\text { (0.0421 gha/visitor) }\end{array}$ & -0.2 \\
\hline $\begin{array}{l}\text { 3. Increase consumption } \\
\text { of organic food and } \\
\text { drink }(100 \%) \text {. }\end{array}$ & $\begin{array}{l}918.1 \\
(0.0126 \text { gha/visitor })\end{array}$ & -35.0 & $\begin{array}{c}2,588.1 \\
(0.0355 \text { gha/visitor })\end{array}$ & -16.0 \\
\hline
\end{tabular}

its transportation into the UK. In the second food scenario, we consider the impact of increased consumption of locally produced food and drink by visitors. The results for this scenario show that increasing visitor consumption of locally produced food and drink by $100 \%$ would only reduce the food Footprint figure by $0.4 \%$ (see Table 5). This small reduction in the Footprint is for two main reasons. First, only a small proportion of the total food and drink consumed by visitors at the event was imported $(0.1 \%)$, the majority of this was beer, lager and wine. Secondly, the energy required for food transportation is relatively small compared to that used for its production and processing.

Conventional food and drink requires more energy and resources to produce compared to that which has been produced organically, as it is grown or reared in a more energy-intensive manner, and this results in a larger Footprint. The third food scenario focuses on increasing visitors' consumption of organic food and drink at the event. Increasing the proportion of organic food and drink consumed by visitors to $100 \%$ could reduce the food Footprint figure by as much as $35 \%$ and the total event Footprint by $16 \%$ (see Table 5). The results from these scenarios suggest that focusing on how food and drink are produced would be more effective in reducing the food Footprint of an event rather than increasing visitor consumption of locally produced food and drink. Changing the types of food and drink items consumed by visitors to low impact alternatives would also be an effective strategy for reducing the food Footprint, but not as effective as the production scenario.

\section{Reducing the impact of event-related waste}

When considering the impact of the food and drink consumed at the event, it is not only the purchase of foods that needs to be considered but also whether or not it is consumed and also the packaging that accompanies it. At the 2004 FA Cup Final, visitors and food and drink businesses generated 59.2 tonnes of waste. This waste created a Footprint figure of 146 gha, of which $80.4 \%$ was attributable to food waste. This was followed by paper and card (10.9\%) 
Table 6. Impact of scenarios on the waste Footprint.

\begin{tabular}{|c|c|c|c|c|}
\hline Scenarios & $\begin{array}{c}\text { Total } \\
\text { landfilled } \\
\text { (tonnes) }\end{array}$ & $\begin{array}{c}\text { Amount } \\
\text { recycled or } \\
\text { composted } \\
\text { (tonnes) }\end{array}$ & $\begin{array}{l}\text { Waste } \\
\text { Ecological } \\
\text { Footprint } \\
\text { (gha/day) }\end{array}$ & $\begin{array}{c}\text { Waste } \\
\text { Ecological } \\
\text { Footprint } \\
\% \text { increase/ } \\
\text { decrease }\end{array}$ \\
\hline $\begin{array}{l}\text { 1. Increased recycling of } \\
\text { paper and card }(30 \%) \text {. }\end{array}$ & 57.4 & 1.7 & $\begin{array}{c}147.6 \\
(0.00202 \text { gha/visitor })\end{array}$ & -2.5 \\
\hline $\begin{array}{l}\text { 2. Increased recycling of } \\
\text { glass }(30 \%) \text {. }\end{array}$ & 48.1 & 11.0 & $\begin{array}{c}149.7 \\
(0.00205 \text { gha/visitor })\end{array}$ & -1.2 \\
\hline $\begin{array}{l}\text { 3. Increased composting of } \\
\text { food waste }(30 \%) \text {. }\end{array}$ & 57.8 & 1.4 & $\begin{array}{c}149.0 \\
(0.00204 \mathrm{gha} / \text { visitor })\end{array}$ & -1.7 \\
\hline $\begin{array}{l}\text { 4. Scenarios A, B and C } \\
\text { combined. }\end{array}$ & 45.0 & 14.2 & $\begin{array}{c}143.4 \\
(0.00196 \mathrm{gha} / \text { visitor })\end{array}$ & -5.3 \\
\hline
\end{tabular}

and glass $(5.3 \%)$. The waste scenarios here consider the impact of increased recycling of paper and card packaging, glass and the composting of food waste. As shown in Table 6, recycling paper and card would bring about the greatest reduction in the waste footprint. For example, recycling $30 \%$ of paper and card packaging could reduce the waste Footprint by $2.5 \%$. This is more than twice as much compared to that achieved by recycling glass or composting food waste. The scenarios presented here suggest that waste strategies which focus on composting food waste and recycling paper and card packaging would bring about the greatest reduction in the waste Footprint, and therefore the overall Footprint of the event.

\section{Conclusions}

Decision makers today have to grapple with the economic and environmental impacts of development strategies. No longer are arguments in favour of income creation or job security sufficient. The environmental dimension of major events cannot be ignored. This paper has demonstrated that events do have potentially large environmental consequences, which should be a consideration when planning future events. It has also demonstrated the value of the EF as an approach from which to understand and measure the global environmental effects associated with staging a major event such as the FA Cup Final.

Our EF analysis of the FA Cup Final has shown that it is a valuable tool which has the ability to isolate those consumption activities (food and drink and transport behaviour) and waste types that have the greatest impact on the Footprint. These impacts may be large and the EF provides both a useful way of communicating the scale of those impacts to decision makers and a wider audience and of suggesting means by which those impacts might be reduced. It also has the potential to illustrate ways in which those pressures might be 
Table 7. Summary of advantages and disadvantages of using the Ecological Footprint to measure the environmental impacts of major events.

Advantages

Aggregates the impact of different activities into a single measure. Compares the total ecological impact of events over time and with other events.

Compares the impact of different visitor consumption activities.

Useful tool and approach to communicate and raise awareness of the environmental impacts of major events.

Develop different policies and assess the extent to which they will reduce the event Footprint.
Disadvantages

Data collection of event-specific consumption can be resource intensive.

Difficulties in accounting for all areas of visitor-related consumption.

Issues relating to data availability for all areas of consumption.

Difficulties in accounting for some displacement effects.

reduced through the development of scenarios. For example, replacing car travel with coach or rail, or replacing conventional food and drink with organic alternatives.

However, the EF when applied to events also has several disadvantages (see Table 7). First, data collection for event-specific consumption can be resource intensive. Second, the method used here did not account for all visitor consumption at the event, for example, energy use in visitor accommodation, due to difficulties in accessing relevant data for the EF calculation. Furthermore, the Footprint as used in this case does not take account of any displacement effects generated by the event, such as reduced consumption by Cardiff residents who did not eat out in the city on match day. The final issue relates to problems of data availability for all areas of consumption, for example, consumables and durables purchased by visitors during their stay.

As the EF methodology relates to the consumption activities of a defined population, it therefore has many potential applications. It could also be applied to a range of events, such as those attended by local residents only or where the boundaries of an event extend beyond the geographical boundary of a city. For example, the Footprint could be applied to an event which takes place across one country, such as the FIFA World Cup, or across several countries, such as the RBS Six Nations Championships. The Footprint could also be applied to mega events such as the Olympic Games, which are held over a longer time period. In the case event presented here, the impact of UK travel only was included, but this could be extended to include visitor travel from abroad.

Sustainable development was an integral part of London's successful bid to host the 2012 Olympic Games and built on the ethos of the Olympic Movement's Agenda 21 (Sport for Sustainable Development) and the International Olympic Committee's Declaration on partnerships for Sustainable Development (London 2012, 2005). The London Organizing Committee for the Olympic and Paralympic Games (LOCOG) have committed in their bid to use lessons learnt from this Footprint Analysis of the FA Cup Final and other environmental pilot 
projects to inform the development of their Environmental and Sustainable Development Programmes. In addition to ensuring that the infrastructure developed for the Games has a limited impact, our study has shown that consideration of how visitors travel to events, their food and drink consumption and the waste they produce will also be important considerations if London is to deliver its vision of making progress towards staging a 'One Planet Olympics' in 2012 .

\section{References}

Ayres, R.U. (2000), 'Commentary on the utility of the Ecological Footprint concept', Ecological Economics, Vol 32, pp 347-349.

Barrett, J., and Scott, A. (2003), 'The application of the Ecological Footprint: a case of passenger transport in Merseyside', Local Environment, Vol 8, No 2, pp 167-183.

Barrett, J., Birch, R., Cherrett, N., and Wiedmann, T. (2005), Reducing Wales' Ecological Footprint - Main Report, Stockholm Environment Institute, University of York; WWF Cymru, Cardiff, http://www.wwf.org.uk/filelibrary/pdf/ef_rdcngwales_full.pdf (last accessed 6 August 2008).

Clarke, A. (2004), 'Evaluating mega-events: a critical review', paper presented at The 3rd Dehaan Tourism Management Conference on The Impact and Management of Tourism-Related Events, December 2004, Nottingham University Business School, Nottingham.

Collins, A., and Flynn, A. (2005), 'A new perspective on the environmental impacts of planning: a case study of Cardiff's International Sports Village', Journal of Environmental Policy and Planning, Vol 7, pp 277-302.

Collins, A., Flynn, A., and Netherwood, A. (2005), 'Reducing Cardiff's' Ecological Footprint Technical Report', BRASS, Cardiff University, WWF Cymru, Cardiff, http://www.cardiff.gov.uk/ content.asp? nav $=2870 \% 2 \mathrm{C} 3148 \% 2 \mathrm{C} 4119$ \&parent_directory_id $=2865$ (last accessed 6 August 2008).

Collins, A., Flynn, A., Wiedmann, T., and Barrett, J. (2006), 'The environmental impacts of consumption at a sub-national level: the Ecological Footprint of Cardiff', Journal of Industrial Ecology, Vol 10, No 3, pp 1-16.

Collins, A., Flynn, A., Munday, M., and Roberts, A. (2007), 'Assessing the environmental consequences of major sporting events: the 2003/04 FA Cup Final', Urban Studies, Vol 44, No 3, pp $1-20$.

Ferng, J.J. (2002), 'Toward a scenario analysis framework for energy footprints', Ecological Economics, Vol 40, pp 53-69.

GFN (2004) National Footprint and Biocapacity Accounts, Global Footprint Network, Oakland, CA, http://www.footprintnetwork.org/gfn_sub.php? content=nrb (last accessed 6 August 2008).

Jones, C. (2001), 'Mega-events and host region impacts: determining the true worth of the 1999 Rugby World Cup', International Journal of Tourism Research, Vol 3, pp 241-251.

Lenzen, M., and Murray, S.A. (2001), 'A modified Ecological Footprint method and its application to Australia', Ecological Economics, Vol 37, pp 229-255.

London 2012 (2005), 'Candidate file. Theme 5: Environment and meteorology', London 2012, London, http://www.london2012.com/documents/candidate-files/theme-5-environment.pdf (last accessed 6 August 2008).

McDonald, G.W., and Patterson, M.G. (2004), 'Ecological Footprints and interdependencies of New Zealand regions', Ecological Economics, Vol 50, pp 49-67.

McGregor, P.G., Swales, J.K., and Turner, K.R. (2004), 'The impact of Scottish consumption on the local environment: an alternative to the Ecological Footprint?' Fraser of Allander Institute, University of Strathclyde, Quarterly Economic Commentary - Economic Perspectives, Vol 29, No 1, pp 29-34.

Martinez-Alier, J. (1990). Ecological Economics: Energy, Environment, and Society, Basil Blackwell, Oxford.

Moffatt, I. (2000), 'Ecological Footprints and sustainable development', Ecological Economics, Vol 32, pp 359-362.

Monfreda, C., Wackernagel, M., and Deumling, D. (2004), 'Establishing national natural capital accounts based on detailed Ecological Footprint and biological capacity assessments', Land Use Policy, Vol 21, pp 231-246. 
Pezzey, J.C., and Toman, M.A. (2002), 'The economics of sustainability: a review of journal articles', Resources for the Future, Discussion Paper 02-03, Washington, DC.

Rees, W.E. (2003), 'Economic development and environmental protection: an ecological economics perspective', Environmental Monitoring and Assessment, Vol 86, pp 29-45.

van den Bergh, J.C.M. (2001), 'Ecological economics: themes, approaches, and differences with environmental economics', Regional Environmental Change, Vol 2, No 1, pp 13-23.

van den Bergh, J.C.J.M., and Verbruggen, H. (1999), 'Spatial sustainability, trade and indicators: an evaluation of the "Ecological Footprint", Ecological Economics, Vol 29, pp 61-72.

van Vuuren, D.P., and Smeets, E.M.W. (2001), 'Ecological Footprints: reply to A.R.B Ferguson', Ecological Economics, Vol 37, pp 2-3.

Wackernagel, M., and Rees, W.E. (1996), Our Ecological Footprint. Reducing Human Impact on the Earth, New Society Publishers, Gabriola Island, British Columbia.

Wiedmann, T., Minx, J., Barrett, J., and Wackernagel, M. (2006), 'Allocating Ecological Footprints to household consumption activities by using Input-Output analysis', Ecological Economics, Vol 56, pp 28-48.

World Wildlife Fund (2006) 'Living planet report 2006', http://www.assets.panda.org/downloads/ living_planet_report.pdf (last accessed November 2006). 